\title{
EL MAR Y LA NAVE. CONSTRUCCIÓN DE SABERES Y VARIACIONES ICONOGRÁFICAS - HISTÓRICAS EN LAS ALEGORÍAS DEL TRIUNFO DE LA IGLESIA CATÓLICA ${ }^{1}$
}

[...] será tu carro triunfal una nave: irá en la gavia Cristo; será tu fanal la Hostia

Lope de Vega, El triunfo de la Iglesia, 1963, pp. 382-395

En este artículo introductorio al dossier "Emblemas, alegorías y otras imágenes del poder. Historias de éxito y fracaso", quisiéramos proponer un acercamiento en torno a la lectura de imágenes a través de las claves hermenéuticas "éxito-fracaso" (Rocco-Lozano, 2020). Realizaremos un ejercicio descriptivo y metodológico de indagaciones libres de imágenes sobre los temas "nave" y "mar" en las alegorías del triunfo de la Iglesia católica en su expansión por el mundo, centrándonos, principalmente, en la alegoría atribuida al autor Miguel Jiménez, "El triunfo de la iglesia" (el vaso de la contemplación mística) del siglo XviII (Museo Nacional del Virreinato, Tepotzotlán). Esto nos ha guiado por diversos caminos

1 Este artículo es parte del proyecto "Failure: Reversing the Genealogies of Unsuccess, 16th-19th Centuries” [WP 3] (H2020-MSCA-RISE, Grant agreement: 823998). 
investigativos y, sobre todo, se ha constituido como una cantera abierta de profundización que no pretende una aproximación teórica, sino más bien de posibilidades metodológicas alimentadas por los estudios de la imagen, la iconología y las trayectorias teóricas de la historia del arte y su profundidad de campo que nutren muchas de las disciplinas humanísticas. Al mismo tiempo, nombres relevantes como Aby Warburg, Erwin Panofsky, Ernst Gombrich, Michael Baxandall, Roberto Longhi, Carlo Ginzburg, Svetlana Alpers, Linda Nochlin, Susan Sontag, Ann Sutherland Harris y Jaynie Louise Anderson, entre otros (Burucúa, 2003), han marcado muchas de las reflexiones sobre las imágenes y el arte en los siglos xx y xxi y, nos han ayudado a aproximarnos a los usos e interpretaciones de las imágenes.

Este dossier tiene el objetivo analizar imágenes en torno a los asuntos del fracaso y del éxito entre los siglos Xvi y xıx. Los artículos discuten cómo la monarquía española y las órdenes religiosas utilizaron imágenes, emblemas y frontispicios de libros para representar o tensionar los fracasos y los éxitos del expansionismo europeo. Así, en estas iconografías vinculadas a las misiones católicas, al panteón celestial, a la burocracia imperial y a la simbología del poder político moderno se puede leer un denso corpus de metáforas sobre las fragilidades y las tensiones del universalismo, el colonialismo externo e interno, y el expansionismo occidental. A partir de la fuerza reconocida de la imagen visual en la época se crearon y adaptaron frontispicios, emblemas y otras imágenes como herramientas de poder, de persuasión, de fijación de ideas y de propaganda entre los siglos Xvi-Xıx. Por esa razón, las preguntas principales que abordan los autores del dossier han sido: ¿en qué medida estas imágenes narran historias de éxito o de fracaso de los individuos, sociedades e instituciones involucradas?; ¿cuán efectivas fueron en su representación del poder?; ¿qué sabemos de su recepción, traducción e impacto?; ¿cómo se percibieron en su época de producción y circulación?; ¿a qué referentes se recurre para ensalzar el éxito?; ¿cuáles son los cambios y continuidades en las representaciones del éxito?; ¿qué relación hay entre una imagen de éxito y una narrativa con ánimos de objetividad?

Las imágenes, al igual que la lectura, son como una caja china. Al observarlas, sin lugar a duda, estamos observando muchas otras, leyendo muchas claves y situándolas en "psicologías de la representación" específicas y contextuales (Gombrich, 2008). Es lo que podemos enunciar teóricamente a través de los vanguardistas términos propuestos por Aby Warburg a inicios del siglo xx: Pathosformeln (repertorio de formas, fórmula 
del pathos) y Nachleben (pervivencia) (Warburg, 2019; Settis, 2012). Estos conceptos nos ayudan a comprender y visualizar las raíces antiguas de imágenes modernas, tal como ha puesto en práctica Carlo Ginzburg al interpretar el frontispicio del Leviathan or the Matter, Forme and Power of a Common-wealth Ecclesiaticall and Civil (1651) de Thomas Hobbes, que traduce las palabras de Tácito: fingunt simul creduntque ("los hombres crean y al mismo tiempo creen en aquello que han creado") (Ginzburg, 2015, pp. 51-80).

En ese sentido, lo que analizaremos en este texto a través de una trayectoria investigativa, y para otorgarle una articulación analítica al dossier, son los gestos, las superposiciones y las pervivencias de una imagen a la que llegamos por azar. Ciertamente, es una imagen conocida por especialistas, catalogada, con un autor atribuido y expuesta en un importante museo mexicano. Por lo tanto, no es una imagen desconocida. Sin embargo, esta llegada azarosa nos abrió posibilidades conjeturales y relaciones históricas con simbolismos y representaciones que pervivieron en las alegorías enmarcadas en el tópico del triunfo de la Iglesia. Son imágenes, como expresa Warburg, que, a pesar de ser universales, son singulares al mismo tiempo. Son imágenes que no pertenecen a una sola época, sino a muchas.

De esta manera, partimos buscando imágenes para un afiche de un seminario, específicamente, en torno a los éxitos y fracasos de las experiencias misioneras en América y Europa en un arco temporal de larga duración ${ }^{2}$. Así como el tema es amplísimo, vasto es también el repertorio de imágenes. Iniciamos por un topos de las experiencias misioneras: el patrono de las misiones y misioneros, el jesuita san Francisco Javier. Inmediatamente surgieron en la búsqueda electrónica los grandes autores de la pintura moderna que lo retrataron en diversas experiencias vitales, como, por ejemplo, Peter Paul Rubens (Los milagros de san Francisco, 1617), Anton van Dyck (La visión de san Francisco, 1622), Nicolas Poussin (Milagros de san Francisco, 1641), Giovanni Battista Gaulli (Visión de San Francisco Javier, 1675) y Francisco de Goya (La muerte de Francisco Javier, 17711774). Desde este corpus reconocidísimo llegamos a varias iconografías barrocas menos conocidas difundidas por todo el orbe católico y que se encuentran extraordinariamente recopiladas por la historiadora María

2 El seminario, titulado "Sobre experiencias misionera. Traducción y circulación de información: fracasos y éxitos en contextos coloniales y europeos”, se ha realizado en el Instituto de Historia de la Pontificia Universidad Católica de Chile durante el 1. ${ }^{\circ}$ y el 2. ${ }^{\circ}$ de octubre del 2020. 
Gabriela Torres Olleta (2009). Sin embargo, en ambos corpus existe un tema transversal modelado, principalmente, por la muerte del santo, la frágil corporalidad de Francisco y sus movimientos en busca de bárbaros y herejes para convertir. Con este amplio catálogo, dos iconografías nos llamaron la atención: las alegorías de Francisco Javier que se vinculan con los temas de la nave y del mar. La figura 1, de Valeriano Regnartio, que se encuentra en S. Francisci Xaverii Ind. Apostoli (Roma, 1622) y representa la narración de Francisco que, desde un barco, convierte el agua salada del mar en agua dulce.

Figura 1. Valeriano Regnartio, S. Francisci Xaverii Ind. Apostoli, Roma, 1622

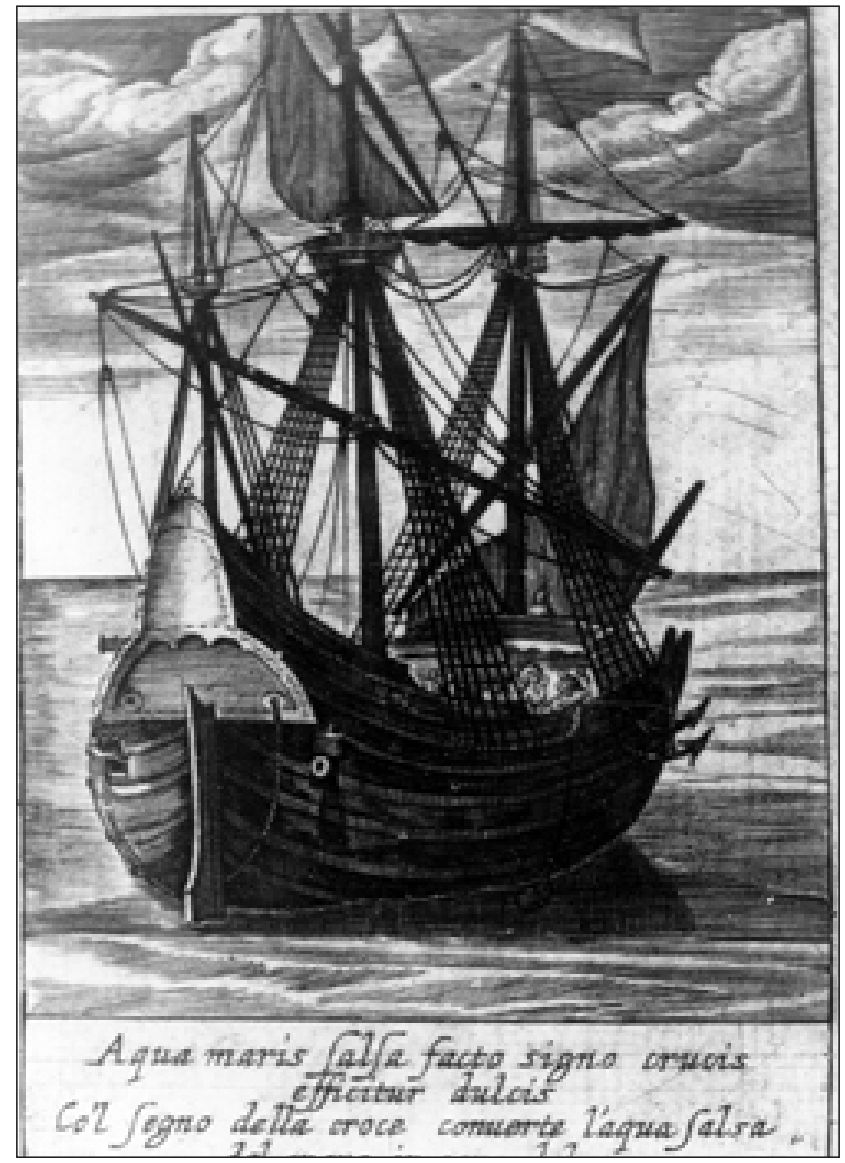

Fuente: Torres-Olleta (2009).

En contraste, en la figura 2, de una mayor complejidad narrativa, aparece Francisco Javier como el "príncipe del mar", tirado por caballos de mar o quizás los hipocampos de Poseidón, custodiado además por dos 
querubines y con un carro en forma de concha marina. Tanto caballos como querubines van surcando las olas que otorgan la velocidad al movimiento de Francisco a través del orbe católico. Aquí, el santo es el domador de caballos y del mar, que transita con una actitud guerrera y con un tridente-bandera-cruz de la Compañía de Jesús. Al fondo, al mismo tiempo, aparecen distintas naves en circulación.

Figura 2. Grabado de J. Villafranca en Lorenzo Ortiz, El príncipe del mar san Francisco Xavier de la Compañía de Jesús, apóstol del Oriente y patrón de sus navegaciones, 1688

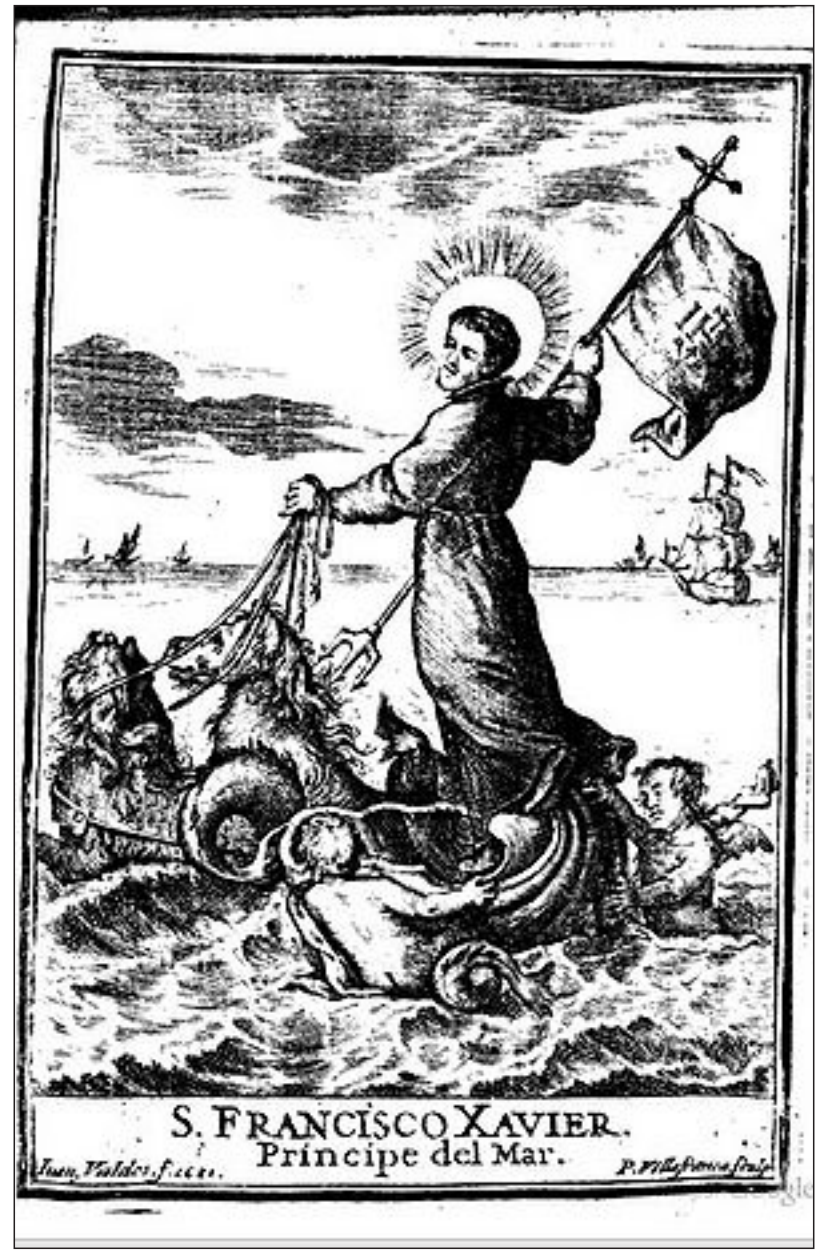

Fuente: Torres-Olleta (2009).

Sin embargo, la obviedad de usar a Francisco Javier en un seminario con especialistas de las misiones católicas nos llevó hacia otra dirección, pero quedándonos con los asuntos del mar y las naves. Estas son partes 
constitutivas de las alegorías del triunfo de la Iglesia en su expansión por el mundo y que retoman las Sagradas Escrituras y el Arca de Noé. Es la representación exitosa de las trayectorias de la fe guiadas por Cristo, las llaves de San Pedro y los apóstoles que se mueven y convierten las tierras de herejes y bárbaros. Son las naves que se mueven por todo el mundo, en todas las direcciones. El mar que circunda las "cuatro partes" del mundo y que es, al mismo tiempo, el mundo y sus peligros. En las iconografías de Francisco Javier, el mar se movía al compás de las experiencias misioneras del santo jesuita. Desde esa búsqueda, en diversos catálogos electrónicos y en Google con las palabras clave triunfo de la Iglesia, "nave" y "mar", la llegada a múltiples imágenes, iconografías, óleos sobre tela y frescos de diversas latitudes geográficas era descontada. Ciertamente, predominaba el magnífico "Triunfo de la Iglesia” de Rubens, que, en vez de una nave y el mar, es un carro tirado por caballos que aplastan a la herejía con violencia en un desfile triunfante guiado por la Iglesia, personificada en una mujer con una lámpara. El caballo principal que tira el carro porta las llaves de san Pedro y san Pablo (Vergara \& Woollett, 2014).

Figura 3. Peter Paul Rubens, El triunfo de la Iglesia, hacia 1625

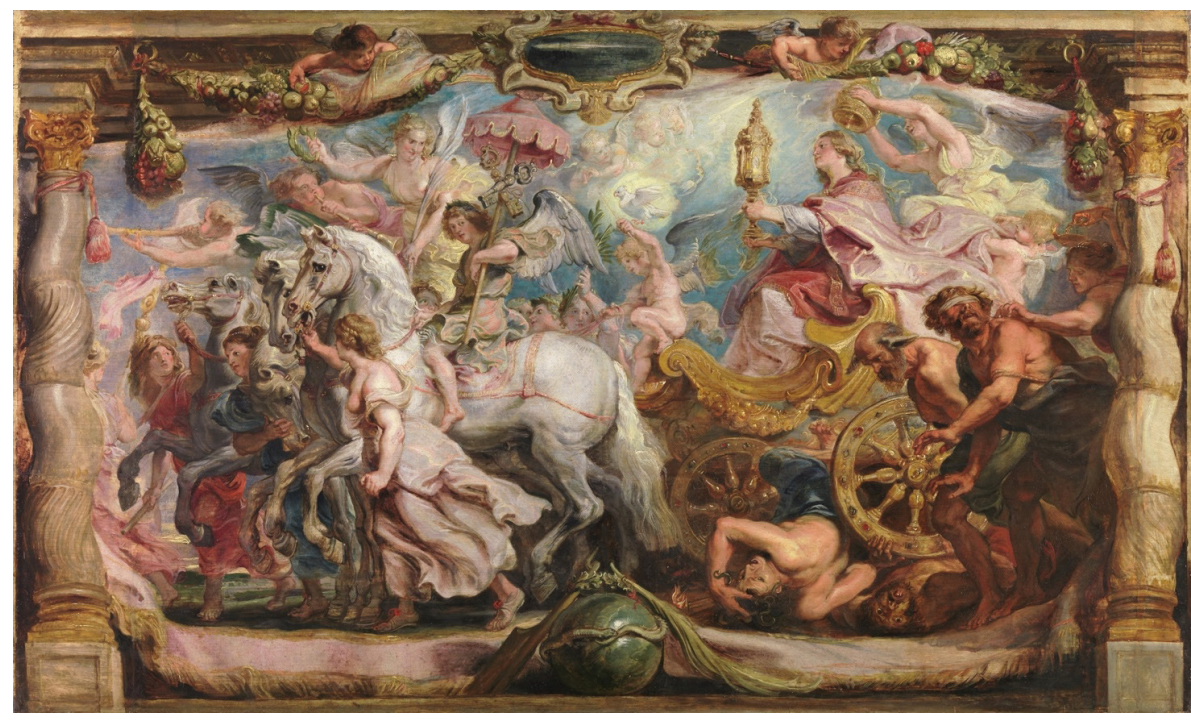

Nota. Museo del Prado, Madrid, España.

Fuente: Museo del Prado (s. f.).

Un elemento fundamental ocurrió con el encuentro electrónico de la imagen de Rubens. Al usar la palabra clave "triunfo de la iglesia", esta nos llevó al óleo sobre tela del conocido y estudiado artista novohispano 
Cristóbal de Villalpando, quien tuvo una intensa actividad artística en Nueva España durante la segunda mitad del siglo Xviı. Esta obra se titulada precisamente El triunfo de la Iglesia, de 1689.

Figura 4. Cristóbal de Villalpando, El triunfo de la Iglesia, 1689

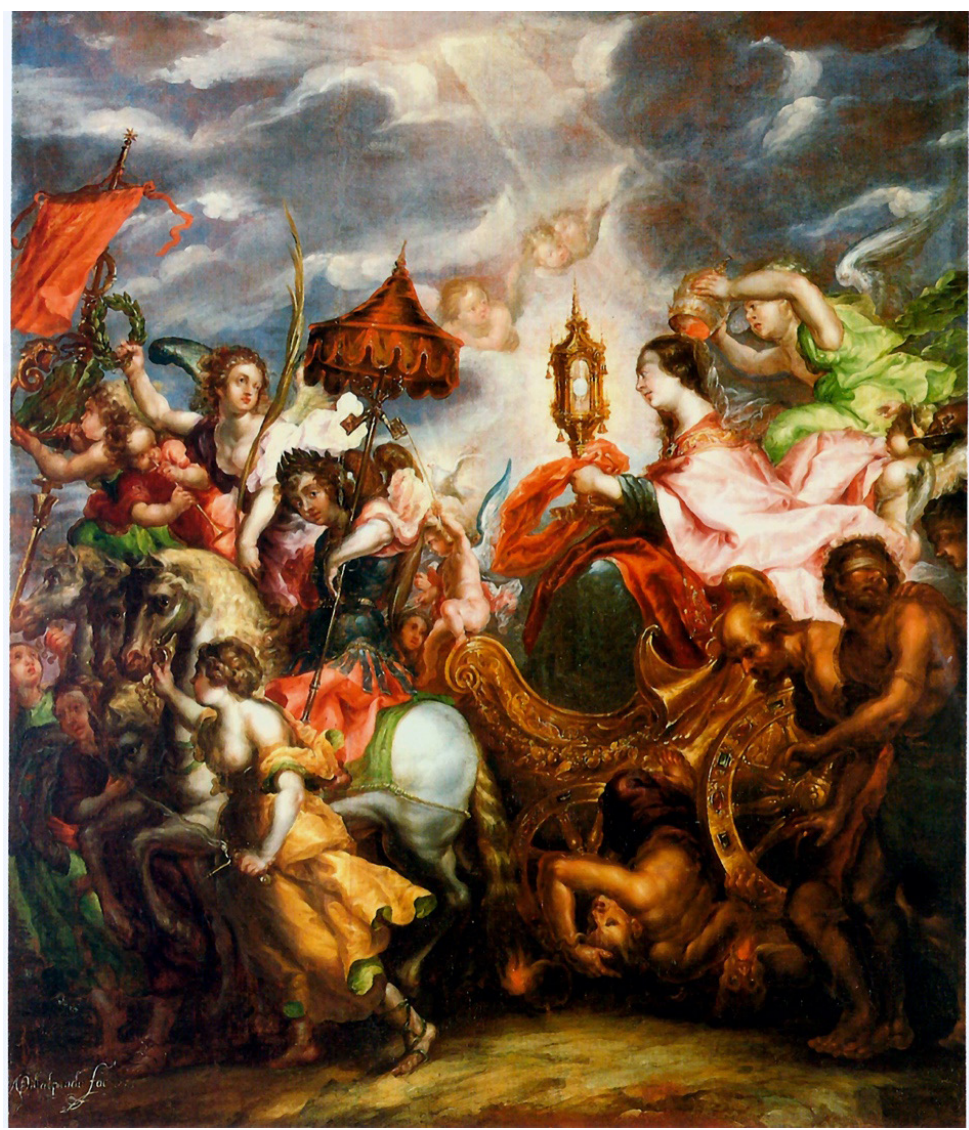

Fuente: ARCA (s. f.).

Claramente, Villalpando usa a Rubens como un modelo, al utilizar el mismo canon, los modelos, la narrativa y los colores, lo que ha sido definido por Aaron M. Hyman como el "canon trasatlántico de Nueva España” (2017, pp. 102-135), presente en el autor novohispano. Sin embargo, no es objetivo de este texto analizar los prestamos creadores de Rubens hacia Villalpando o bien las traducciones que se hacen desde Nueva España de la pintura barroca flamenca del siglo XVII (Sigaut, 1989, pp. 315-372; Von Kügelen, 2008, pp. 1.009-10.078), sino más bien constatar la evidente circulación de un modelo artístico en torno a las alegorías del "triunfo de la Iglesia", que repercute también en las formas artísticas americanas. 
Ha sido importante el cruce entre Rubens y Villalpando en torno al tema del triunfo de la Iglesia, ya que, desde ahí, la búsqueda nos guio hacia otras formas de representar esa alegoría. Desde ese intersticio aparecieron las alegorías del triunfo de la iglesia, pero esta vez, retomando el tópico del mar y la nave, aludiendo probablemente a la distancia marino-atlántica que separa a América del resto del Orbis Terrarum. No hay que olvidar que una de las primeras alegorías del triunfo de los valores católicos en la expansión del cristianismo hacia tierras americanas lo constituye aquella barca con las virtudes teologales que mostraba los pilares de Hércules y la inscripción plus ultra, utilizada por Felipe II para los funerales de su padre Carlos V. La obra en cuestión es de Jean y Lucas Doetecum y fue impresa en Amberes en los talleres Cristóbal Plantin en 1559 (figura 5). Su significado iconológico refiere al triunfo de Europa y de la cristiandad, que han logrado sortear el obstáculo del Atlántico y materializar el legendario non plus ultra en plus ultra.

Figura 5. Jean y Lucas Doetecum, La magnifique et sumptueuse pompe funèbre faite aus obseques et funerailles du tresgrand et tresvictorieus empereur Charles Cinquième, celebrées en la Vile de Bruxelles le XXIX Iour du mois de decembre MDL VII par Philippes roy catholiques d’Espaigne son fils, 1559

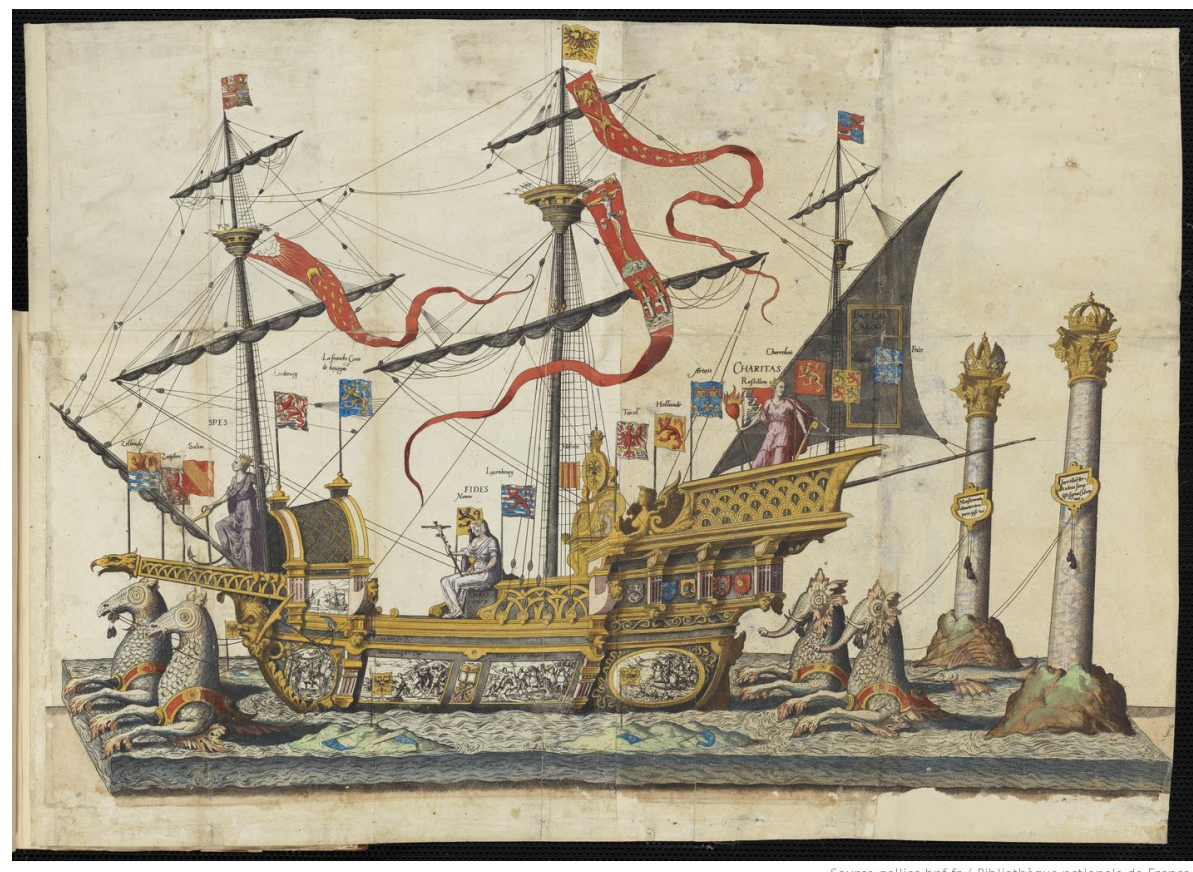

Fuente: Anvers (1559). 
Del mismo modo, apareció el conocido mural de Melchor Pérez de Holguín, El triunfo de la Iglesia (1706), de la Iglesia de San Lorenzo, Potosí, Bolivia, así como también algunos anónimos de la Escuela Cuzqueña. Inmediatamente pensamos en el mosaico fragmentado del Giotto, Navicella (Venturi, 1922, pp. 49-69; Köhren-Jansen, 1993), que se encuentra en el atrio de la Basílica de San Pedro en el Vaticano. Ese mosaico narra la caminata de Cristo sobre el agua para salvar a Pedro en medio de una tormenta descrito en Mateo (14:22-32):

Después de esto, Jesús hizo que sus discípulos subieran a la barca, para que cruzaran el lago antes que él y llegaran al otro lado mientras él despedía a la gente. Cuando la hubo despedido, Jesús subió a un cerro, para orar a solas. Al llegar la noche, estaba allí él solo, mientras la barca ya iba bastante lejos de tierra firme, las olas azotaban la barca, porque tenía el viento en contra. A la madrugada, Jesús fue hacia ellos caminando sobre el agua. Cuando los discípulos lo vieron andar sobre el agua, se asustaron, y gritaron llenos de miedo:

¡Es un fantasma!

Pero Jesús les habló, diciéndoles:

¡Calma! Soy yo: no tengan miedo.

Entonces Pedro le respondió:

Señor, si eres tú, ordena que yo vaya hasta ti sobre el agua.

Pedro entonces bajó de la barca y comenzó a caminar sobre el agua en dirección a Jesús. Pero al notar la fuerza del viento, tuvo miedo; y como comenzaba a hundirse, gritó:

¡Sálvame, Señor!

Al momento, Jesús lo tomó de la mano y le dijo: ¿Qué poca fe tienes! ¿Por qué dudaste? En cuanto subieron a la barca, se calmó el viento. Entonces los que estaban en la barca se pusieron de rodillas delante de Jesús, y le dijeron: ¡En verdad tú eres el Hijo de Dios!

Giotto, en ese mosaico, retomaba episodios evangélicos que se volvieron fuente de la literatura cristiana desde san Ambrosio y san Agustín hasta santo Tomás de Aquino, quienes interpretaron la nave como símbolo de la salvación de la Iglesia, el mar como el mundo y Pedro como pescador de hombres; además, la nave se entiende como un símbolo litúrgico y en una metáfora de los predicadores hasta el siglo XVII (Baxandall, 1996; Calbarro, 2002, pp. 293-317). Sin embargo, las alegorías del triunfo de la iglesia complejizan el episodio evangélico y la nave de san 
Pedro se convierte en una variante que narra también episodios históricos y contextuales de la época de la Reforma y disputas confesionales, y, como expresa Paolo Prodi, el arte deja la "especulación teológica" y se convierte en un instrumento de devoción, pertenencia confesional, disciplinamiento religioso y elemento de confrontación política, así como de manifestación de poder (Prodi, 2014). Así, el auge de las alegorías de la Iglesia militante y triunfante sobre otras confesiones alcanzó su esplendor en los tiempos de la Reforma y Reforma católica (Prosperi, 1996). La pista mayor, en ese sentido, de la circulación de un modelo de alegoría militante entre Europa y América en la edad moderna fue proporcionada por Santiago Sebastián, quien, en su libro Iconografía e iconología del arte novohispano (1992, p. 29), indica la existencia de un grabado romano de inicios del siglo xvir, Triumphus Ecclesiae (Roma, 1602), que tuvo una gran fortuna de reproducción en Europa. Aunque Sebastián italianizó el nombre del grabador francés Philippe Thomassin (1562-1622) por Filippo Tomassini, que ciertamente puede confundirse con el nombre del obispo Giacomo Filippo Tomassini, llegamos al grabado romano que, según Gabriel Llompart (1976, pp. 281-300), fue reproducido posteriormente en Milán y luego utilizado como modelo, por ejemplo, para el mural de Melchor Pérez Holguín en Potosí, entre otras versiones americanas.

Ese grabado romano, que se inspira en la nave de san Pedro, pero que incluye el contexto de producción de las batallas en contra de herejes en tiempos de la Reforma, diversos episodios bíblicos, procesos de conversión, milagros y la derrota del paganismo clásico, encuentra una réplica coloreada y casi exacta en el óleo sobre tela atribuido a Miguel Jiménez, El triunfo de la Iglesia (el vaso de la contemplación mística) del siglo XviII. El óleo posee la misma composición que el grabado, los mismos personajes y narrativa. En sus cuatro esquinas, al igual que en el grabado, presenta eventos importantes de los triunfos del cristianismo, como, por ejemplo, la conversión de los turcos en Constantinopla (arriba izquierda), la conversión de Pablo en Damasco basado en Hechos (9: 4) (arriba derecha), el rechazo de la idolatría en tiempos de Nabucodonosor II y los condenados rescatados por un ángel (abajo izquierda) y la batalla entre el persa Cosroes II y el emperador bizantino Heraclio en 615 (abajo izquierda). En su parte inferior, al medio, una roca que representa las Sagradas Escrituras cae sobre los herejes proveniente de Mateo (16: 18). 


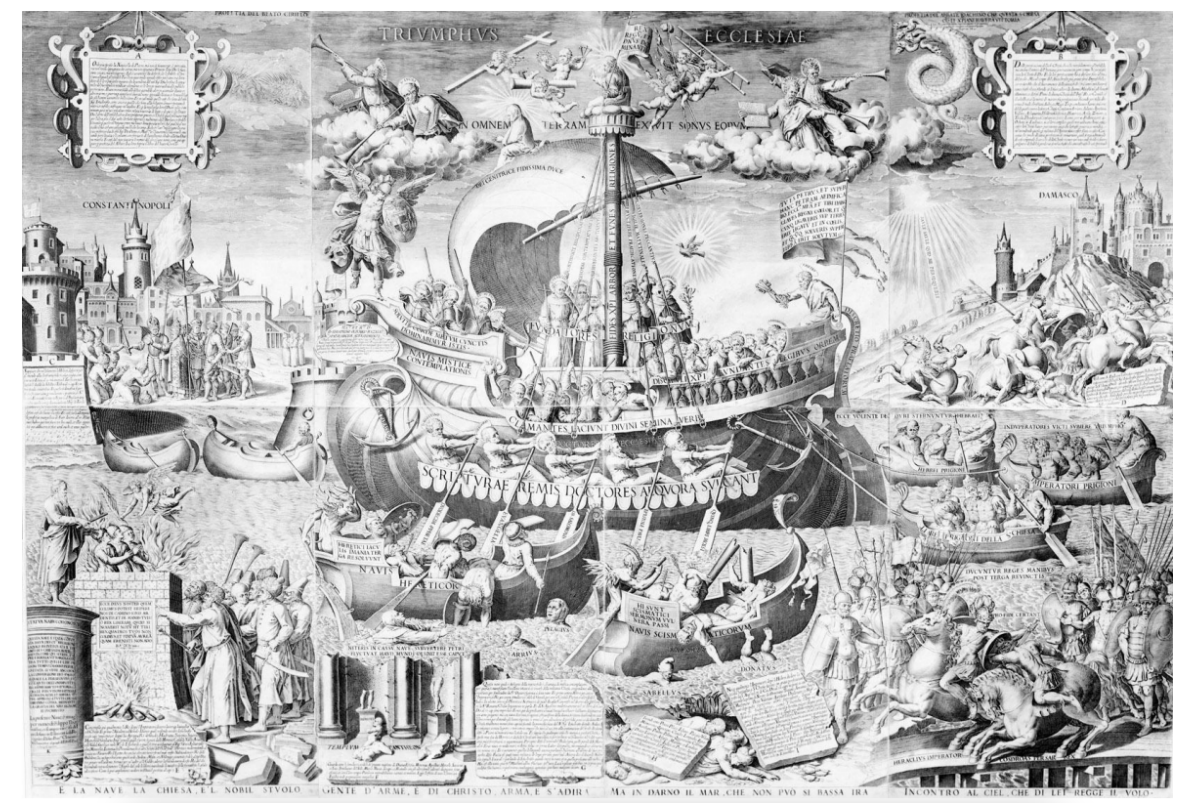

Nota. Biblioteca Casanatense, Roma ${ }^{3}$.

Es una alegoría militante y triunfante que tiene además a Lutero, Beza (Théodore de Bèze), Arreo, Calvino y Sabelio ahogándose bajo la mirada de los doctores de la Iglesia, quienes protegen la nave (san Ambrosio, san Gregorio, san Jerónimo, san Agustín y santo Tomás). El grabado italiano incluye también a Pelagio y Donato Magno como herejes ahogándose. Dentro de la barca, junto a los apóstoles guiados por san Pedro, quien tiene las llaves y el timón, se encuentran los fundadores de las órdenes religiosas, quienes, con cuerdas, se unen al mástil donde se encuentra Cristo y a su lado la Virgen en la parte superior y, al mismo tiempo, atacan junto al arcángel san Miguel a los herejes en el mar. Aquí hay una pequeña diferencia entre el grabado y el óleo: mientras que en el grabado italiano no aparece san Ignacio, en el óleo novohispano aparece Ignacio tirando una lanza con el emblema de la Compañía a los herejes que están en el mar.

A un costado de Cristo y la Virgen hay unos ángeles que portan la cruz, la columna, el látigo, la lanza, el martillo y la escalera,

3 El grabado se encuentra en el sitio "Cataloghi e collezioni digitali delle biblioteche italiane" (http://www.internetculturale.it/) 
representaciones del calvario. En las nubes, se encuentran los evangelistas Mateo, Marcos, Lucas, Juan, quienes con sus trompetas difunden la palabra de Cristo. La nave incluso arrastra tres pequeños botes y en el grabado se logra distinguir quiénes son sus ocupantes: emperadores, reyes, judíos y musulmanes como prisioneros de la Iglesia. Además, justo al lado de la escena del rechazo de la idolatría, aparecen columnas con los nombres Apolo y Hércules como la caída de los ídolos y del paganismo. La alegoría articula en una sola composición la historia de los éxitos del cristianismo y del catolicismo en la conversión religiosa como un proceso continuo, sin fisuras ni oposiciones. Es una perspectiva apologética que transita desde la nave de san Pedro que confirma a Cristo como hijo de Dios, a la nave guerrera y violenta que aplasta y ahoga herejes y paganos.

Figura 7. Miguel Jiménez (atribuido), El triunfo de la iglesia (el vaso de la contemplación mística), siglo XVIII

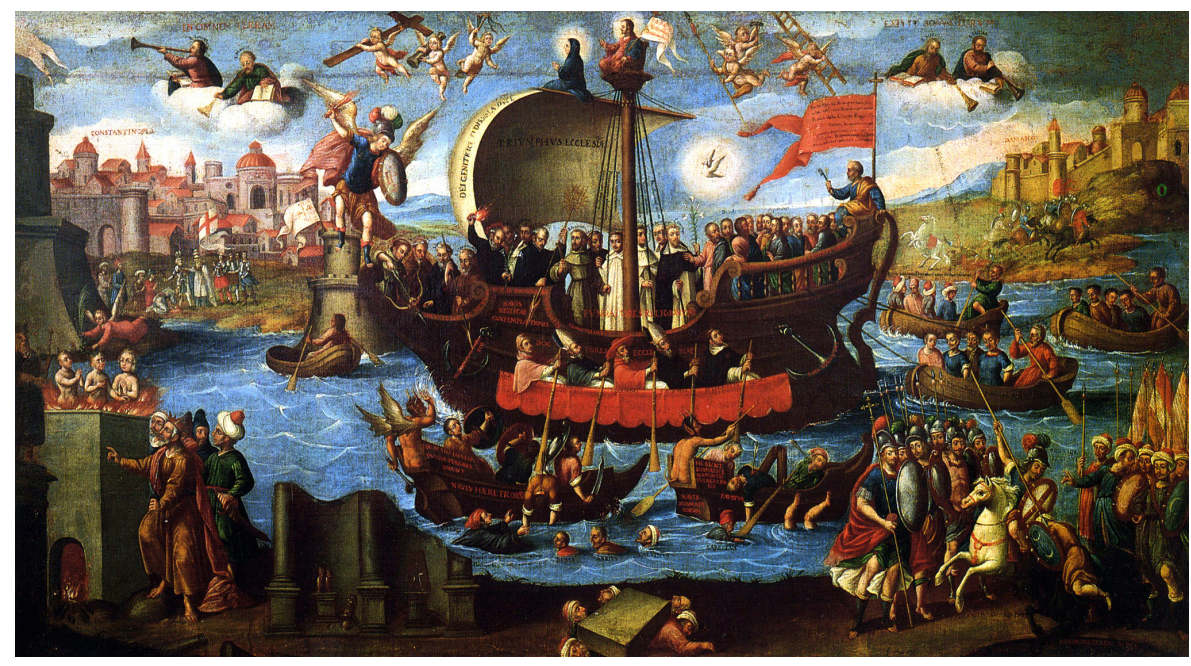

Nota. Museo Nacional del Virreinato, Tepozotlán, México.

Fuente: Instituto Nacional de Antropología e Historia (s. f.).

El recorrido metodológico del "descubrimiento" del óleo novohispano, conocido ciertamente para especialistas, deja muchas preguntas abiertas: por ejemplo, si el artista utilizó el grabado italiano o bien se inspiró en otro. En una primera impresión, claramente, el artista novohispano realiza una "copia certificada" del original, rescatando al mismo tiempo de modo oblicuo una tradición figurativa y plástica proveniente desde el arte paleocristiano. Sin embargo, la mayor pregunta que emerge es por qué el artista no incorporó tópicos propiamente 
americanos en la composición y la representación de eventos históricos. El artista se basó en una tradición figurativa de la representación de la Iglesia que se mueve por el mundo convirtiendo y propagando la fe y que, además, encuentra en la nave y en el mar un canon indiscutible en un mundo moderno donde el catolicismo era una minoría (Romano, 2016).

Ahora bien, toda historia posee su reverso, y el éxito católico que representaban estas alegorías tiene también su propia reversibilidad: podemos observar que el mundo protestante, europeo del norte y católico crítico de Roma comienzan en los tiempos preluteranos y posluteranos una búsqueda figurativa y literaria en torno a la representación de la nave de la Iglesia católica, pero, esta vez, desde una óptica satírica, burlesca y abiertamente polémica. Casos como los de Sebastian Brant en Das Narrenschiff (1494), Jerónimo Bosch en La nave de los locos (1503-1504) y Erasmo de Rottedam en el Elogio de la Locura (1511) son los máximos exponentes de esa reversibilidad. El triunfo y las alegorías, los éxitos y los fracasos tienen también otros rostros.

\section{Rafael Gaune}

Profesor asociado del Instituto de Historia, Pontificia Universidad Católica de Chile, Chile https://orcid.org/0000-0002-7868-4380

rgaune@uc.cl

\section{Olaya Sanfuentes}

Profesora titular del Instituto de Historia, Pontificia Universidad Católica de Chile, Chile https://orcid.org/0000-0002-6951-1285 osanfuen@uc.cl

https://doi.org/10.21789/25007807.1718

\section{REFERENCIAS}

Anvers, A (Ed.). (1559). La magnifique et sumptueuse pompe funèbre faite aus obseques et funérailles du trèsgrand et trèsvictorieus empereur Charles cinquième, célébrées en la ville de Bruxelles le XXIX. jour du mois de décembre M.D.LVIII. par Philippes Roy catholique d'Espaigne son fils. A Anvers, de l'imprimerie de Christophle Plantin. https://gallica.bnf.fr/ark:/12148/bpt6k310602f/f12.item\# 
ARCA. (s. f.). Triunfo de la iglesia. Alegorías y emblemas. http://artecolonialamericano. az.uniandes.edu.co:8080/artworks/542

Baxandall, M. (1996). Giotto y los oradores. La visión de la pintura en los humanistas italianos y el descubrimiento de la composición pictórica 1350-1450. Visor.

Burucúa, J. E. (2003). Historia, arte, cultura. De Aby Warburg a Carlo Ginzburg. Fondo de Cultura Económica.

Calbarro, J.L. (2002). Navis ecclesiae. Origen e interpretación de una joya iconográfica de Betancuria. Tebeto. Anuario del Archivo de Histórico Insular de Fuerteventura, 15, 293-317.

Ginzburg, C. (2015). Rileggere Hobbes oggi. En Paura, reveranza, terrore. Cinque saggi di iconografía politica (pp. 50-80). Adelphi.

Gombrich, E. (2008). Arte e ilusión. Estudio sobre la psicología de la representación pictórica. Phaidos.

Hyman A. M. (2017). Inventing Painting: Cristóbal de Villalpando, Juan Correa, and New Spain's Transatlantic Canon. The Art Bulletin, 99(2), 102-135. https://doi.org/10.1080/00043079.2016.1249251

Instituto Nacional de Antropología e Historia. (s. f.). El triunfo de la Iglesia. http:// mediateca.inah.gob.mx/repositorio/islandora/object/pintura\%3A2291

Köhren-Jansen, H. (1993). Giottos Navicella (Vol. 8). Bibliotheca Hertziana, Max Planck Institute.

Llompart, G. (1976). La nave de san Pedro y sus afines en la Corona de Aragón. Revista de Dialectología y Tradiciones Populares, 32, 281-300.

Museo del Prado. (s. f.). El triunfo de la Iglesia. https://www.museodelprado.es/ coleccion/obra-de-arte/el-triunfo-de-la-iglesia/a07ba8b0-f1db-4d9a-a7cdc103422d8f16

Vega Carpio, L. (1963). El triunfo de la Iglesia. En M. Menéndez Pelayo (Ed.), Obras de Lope de Vega, 7. Autos y Coloquios II (pp. 382-395). Atlas.

Prodi, P. (2014). Arte e pietà nella Chiesa tridentina. Il Mulino.

Prosperi, A. (1996). Tribunali della coscienza. Inquisitori, confessori, missionari. Einaudi.

Romano, A. (2016). Impressions de Chine. L'Europe et l'englobement du monde (XVI'XVII siècle). Fayard.

Sebastián, S. (1992). Iconografia e iconología del arte novohispano. Grupo Azabache.

Settis, S. (2012). Aby Warburg, il demone della forma. Antropologia, storia, memoria. Engramma, 100. http://www.engramma.it/eOS/index.php?id_ articolo $=1139$

Sigaut, N. (1989). Una tradición plástica novohispana. En H. Pérez Martínez (Ed.), Lenguaje y tradición en México (pp. 315-372). Colegio de Michoacán.

Torres-Olleta, M. G. (2009). Redes iconográficas: San Francisco Javier en la cultura visual del barroco. Iberoamericana, Vervuet. https://doi. org/10.31819/9783865279675

Venturi, L. (1922). La Navicella di Giotto. L’Arte, 25, 49-69.

Vergara, A. \& Woollett, A. (2014). Rubens. El triunfo de la Eucaristía. Museo Nacional del Prado, J. Paul Getty Museum. 
Von Kügelen, H. (2008). La pintura de los reinos y Rubens. En J. Brown \& J.

Gutiérrez Haces (Eds.), Pintura de los reinos: Identidades compartidas; Territorios del mundo hispánico, siglos XVI-XVIII (Vol. 4, pp. 1.009-1.078). Fomento Cultural Banamex.

Warburg, A. (2019). La pervivencia de las imágenes. Miluno. 